\title{
SERIAL STUDIES OF THE PER ORAL GLUCOSE TOLERANCE TEST AT THE ANNUAL PHYSICAL EXAMINATIONS
}

\author{
Kempei MATSUOKA $†$ and Ryozaburo ETOH ${ }^{\dagger}$
}

The glucose tolerance is often altered by various physical status including the age factor. Serial studies of the $100 \mathrm{~g}$ per oral glucose tolerance test (GTT) were done in male employees of SONY Corporation at annual physical examinations with 48 hour admission to Saiseikai Central Hospital. The results were classified by the criteria authorized by the Japanese Diabetic Society.

Out of 356 cases of one point study 158 cases showed normal pattern, 170 borderline and 28 diabetic. The incidence of abnormal ST on EKG and abnormal fundoscopic findings were higher in the group of diabetic pattern, while more frequent were the abnormalities of serum cholesterol and from liver function tests in the group of borderline pattern. Comparing these Sony employees to the male employees of a bank (shown as Q bank in Table 7) with higher incidence of obesity over the age 40 , no difference in the rate of abnormal GTT was found. So it seems that the obesity is not always a genetic factor of diabetes mellitus and the prevalence of diabetic diathesis is the same in each firm.

Serial studies of GTT was done in 156 cases by multiple admissions for two times or more during the period of 5 years. More than one half of the cases altered to another pattern of GTT and 75 cases remained unchanged. Furthermore different results were obtained in serum cholesterol and liver function tests. The group of cases which had continuously showed or had once showed diabetic pattern of GTT had higher incidences of abnormal serum cholesterol, abnormal liver function, hypertension, ST abnormality and absent ankle jerks.

Although GTT is said to be the most reliable test to diagnose diabetes mellitus, the diagnosis has to be made considering other physical status, and careful follow up of GTT is necessary for borderline cases.

インスリンが発見されて50年経つのに糖尿病の発病の 時期とか晾断についてはいまだに議論の多いとてろであ る1). 近年日本人の食生活の変化により日本人の糖尿病 患者数は增加して打り, さらに企業等での定期健康診断 の普及や, 人間ドックによりとくに軽症, 初期の糖尿病 患者が多く発見されるようになった2). この調査は一企 業体内に扣ける働き盛りの男子のブドウ糖負荷試験の成 績を検討したものである.

* 済生会中央病院内科

** ソニー株式会社健康管理室 昭和 47 年 10 月 5 日受付

† Department of Internal Medicine, Saiseikai Central Hospital

$+\dagger$ Health Administration, SONY Corporation

Received for publication, October 5, 1972

\section{対象および方法}

昭和 42 年 9 月より 47 年 6 月末日までの 4 年10力月間に ソニー株式会社より済生会中央病院短期人間ドックに入 院した 550 人の中から，ソニー本社健康管理室管轄下の 男子356名について100 g 経ロブドウ糖負荷試験(以下 100 g G.T.T.) の成績と, 他の所見の中から, 血中コレステ ロール, 眼底所見, 蛋白尿, 高血圧, 心電図, 胸部 X線 写真, 肝機能検査, 胃, 十二指腸透視, 胆のう造影等の 所見を比較検討した.ささら，その中より 2 回以上ドッ

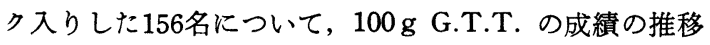
を調査し, 先に述べた他の病態と比較し, one point

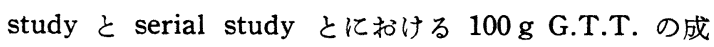

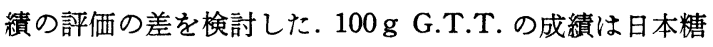


Table 1. The criteria of $100 \mathrm{~g}$ per oral glucose tolerance test (true sugar, $\mathrm{mg} / 100 \mathrm{~m} l$ ) authorized by the Japanese Diabetic Society.

\begin{tabular}{l|r|r|r|r}
\hline \multirow{2}{*}{ Blood } & \multicolumn{2}{|c|}{ Normal pattern } & \multicolumn{2}{c}{ Diabetic pattern } \\
\cline { 2 - 5 } & Capillary & Venous & Capillary & Venous \\
\hline Fasting & $<100$ & $<100$ & - & - \\
1 hour & $<160$ & $<140$ & $>180$ & $>160$ \\
2 hours & $<120$ & $<110$ & $>160$ & $>150$ \\
\hline
\end{tabular}

Table 2. Subjects classified by age and pattern found in one point study.

\begin{tabular}{c|c|c|r|r}
\hline Age (yrs.) & Normal pattern & Borderline & Diabetic pattern & Total \\
\hline$\sim 30$ & 11 & 3 & 0 & 14 \\
$31 \sim 35$ & 31 & 28 & 3 & 62 \\
$36 \sim 40$ & 56 & 68 & 8 & 132 \\
$41 \sim 45$ & 27 & 22 & 7 & 56 \\
$46 \sim 50$ & 24 & 37 & 9 & 70 \\
$51 \sim 55$ & 7 & 10 & 1 & 18 \\
$56 \sim 60$ & 1 & 2 & 0 & 3 \\
$61 \sim$ & 1 & 0 & 0 & 1 \\
\hline Total & 158 & 170 & 28 & $356^{*}$ \\
\hline
\end{tabular}

* No females are included.

尿病学会の診断基準（Table 1）に従い，血中ブドウ糖 の定量は glucose oxydase 法を用いた。

\section{結 果}

1) 1 回入院した356例の検討

年龄別, G.T.T. 型別に分類すると Table 2 打よび 3 のとおりである. 境界型が 170 例と全体の半数近くを 占める．年齢別に見ると糖尿病型がやや高いが有意差は ない. 体型との関係は境界型, 糖尿病型と G.T.T. の成 績が悪くなるにしたがって肥満の頻度が増加し, 肥満頻 度は正常型 $13.9 \%$ 糖尿病型 $42.9 \%$ であった。

血中総コレステロール (Zack Henry 法) は $250 \mathrm{mg} /$ $\mathrm{d} l$ 以上のものを異常とした。異常頻度は境界型に打い て最も高く9.4\%であった. 眼底所見で Keith Wagener 2 度以上または糖尿病性網膜症を指摘された例は糖尿病 型群に多かった，尿蛋白は定性で（十）以上のものを異 常としたが，常在性であるとはいえず，境界型例に高頻 度であった．高血圧も 1 回のみの測定であるため, 高血 圧症とはいえないが，心電図上の ST の異常とともに糖 疗病型例に高頻度である. 肺結核は全例陳旧 性のもの で，陳旧性浸潤像もしくは石灰化像のあるもののみを取 り上げ軽度の胸膜癒着像は除外したが, G.T.T. 型別に
差は認められなかった. 肝障害は, 短期人間ドックで検査 する SGOT, アルカリフォスファターゼ, Z.T.T., より SGOT 50単位以上, アルカリフォスファターゼ $11 \mathrm{KAU}$ 以上, Z.T.T. 12単位以上, の何れか 1 項目を満すもの を異常としたが，境界型例に異常頻度が高かった。ま た, 胃, 胆のう透視所見とは有意の関連はないが胃切除 を受けていた 3 例中 Oxyhyperglycemia を呈した例は 1 例のみであった。

2） 2 回以上入院した例についての検討

2 回以上ドックにはいった 156 例中, 2 回入院 91 人, 3 回入院 45 人， 4 回以上 20 人であった.これらの中で 1 回目の入院時, 正常型66例, 境界型79例, 糖尿病型11例 であったが， 2 回目に，同じ G.T.T. の型に止まった例 は, 正常型 $57.6 \%$, 境界型 $57 \%$ 糖尿病型 $45.5 \%$ に減る. さらに 3 回以降は症例数が減るが, 正常型は 18 例中 9 例, 境界型23例中 14 例, 糖尿病型 4 例中 2 例が 3 回とも 同じ型の中にはいった. 調查の最終結果は Table 4 に 示すとおりであるが，正常型を続けた例は29例で，第 1 回目に正常型を示した66例中の $43.9 \%$, 糖尿病型を続け た例は11例中 5 例で $45.5 \%$ であった．したがって半数以 上が他の型に移行したことになる. そこで便宜上, 次の 4 群に分類した. 
Table 3. Relation between G.T.T pattern and other findings in one point study on 356 cases.

\begin{tabular}{|c|c|c|c|c|c|c|}
\hline \multirow[t]{2}{*}{ G.T.T. Pattern } & \multicolumn{2}{|c|}{ Normal: 158 cases } & \multicolumn{2}{|c|}{ Borderline: 170 cases } & \multicolumn{2}{|c|}{ Diabetic : 28 cases. } \\
\hline & No. & $\%$ & No. & $\%$ & No. & $\%$ \\
\hline \multicolumn{7}{|l|}{ Physique } \\
\hline Obese & 22 & 13.9 & 38 & 22.4 & 12 & 42.9 \\
\hline Normal & 104 & 65.8 & 110 & 64.7 & 10 & 35.7 \\
\hline Thin & 32 & 20.3 & 22 & 12.9 & 6 & 21.4 \\
\hline \multicolumn{7}{|l|}{ Serum cholesterol } \\
\hline$>250 \mathrm{mg} / 100 \mathrm{ml}$ & 7 & 4.5 & 16 & 9.4 & 1 & 3.6 \\
\hline \multicolumn{7}{|l|}{ Ocular fundi } \\
\hline Keith-Wagener & 2 & 1.3 & 2 & 1.2 & 2 & 7.1 \\
\hline Wagener & 0 & - & 0 & - & 1 & 3.6 \\
\hline Albuminuria & 7 & 4.5 & 19 & 11.2 & 1 & 3.6 \\
\hline Hypertention & 10 & 6.6 & 10 & 5.9 & 3 & 10.7 \\
\hline ST abnormality in EKG & 9 & 6.0 & 23 & 13.3 & 4 & 14.3 \\
\hline \multicolumn{7}{|l|}{ Infectious disease } \\
\hline Old pulmonary tbc. & 14 & 9.3 & 15 & 8.8 & 2 & 7.1 \\
\hline Urinary tract & 0 & - & 3 & 1.8 & 0 & - \\
\hline Upper respiratory & 2 & 1.3 & 3 & 1.8 & 1 & 3.6 \\
\hline \multicolumn{7}{|l|}{ Digestive disease } \\
\hline Liver damage & 13 & 8.6 & 25 & 14.7 & 2 & 7.1 \\
\hline Peptic ulcer & 5 & 3.3 & 5 & 3.0 & 1 & 3.6 \\
\hline Stomach cancer & 0 & - & 1 & 0.6 & 0 & - \\
\hline Gall stone & 2 & 1.3 & 3 & 1.8 & 1 & 3.6 \\
\hline Resected stomach & 2 & 1.3 & 1 & 0.6 & 0 & - \\
\hline
\end{tabular}

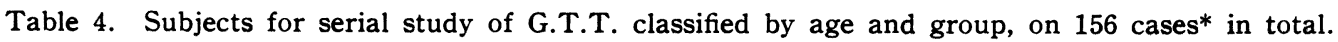

\begin{tabular}{|c|c|c|c|c|}
\hline $\begin{array}{l}\text { Age on the first } \\
\text { admission } \\
\text { (years) }\end{array}$ & $\begin{array}{l}\text { Group I } \\
\mathrm{N} \longrightarrow \mathrm{N}\end{array}$ & $\begin{array}{c}\text { Group II } \\
\mathrm{N} \longrightarrow \mathrm{B}: 32 \\
\mathrm{~B} \longrightarrow \mathrm{N}: 23 \\
\mathrm{~N} \rightarrow \mathrm{B} \rightarrow \mathrm{N}: 4 \\
\mathrm{D} \longrightarrow \mathrm{N}: 1\end{array}$ & $\begin{array}{l}\text { Group III } \\
\mathrm{B} \longrightarrow \mathrm{B}: 41 \\
\mathrm{~B} \rightarrow \mathrm{N} \rightarrow \mathrm{B}: 3\end{array}$ & $\begin{array}{c}\text { Group IV } \\
\text { B } \longrightarrow \text { D : } 12 \\
\text { D } \longrightarrow \text { B : } 5 \\
\mathrm{~N} \longrightarrow \mathrm{D}: 1 \\
\mathrm{D} \longrightarrow \mathrm{D}: 5\end{array}$ \\
\hline$\sim 30$ & 1 & 0 & 0 & 0 \\
\hline $31 \sim 35$ & 5 & 9 & 9 & 2 \\
\hline $36 \sim 40$ & 17 & 19 & 20 & 12 \\
\hline $41 \sim 45$ & 6 & 11 & 11 & 4 \\
\hline $46 \sim 50$ & 0 & 9 & 4 & 4 \\
\hline $51 \sim$ & 0 & 2 & 0 & 1 \\
\hline Av. age (yrs.) & 37.7 & 37.8 & 39.8 & 40.6 \\
\hline Total No. & 29 & 60 & 44 & 23 \\
\hline \multicolumn{5}{|c|}{ 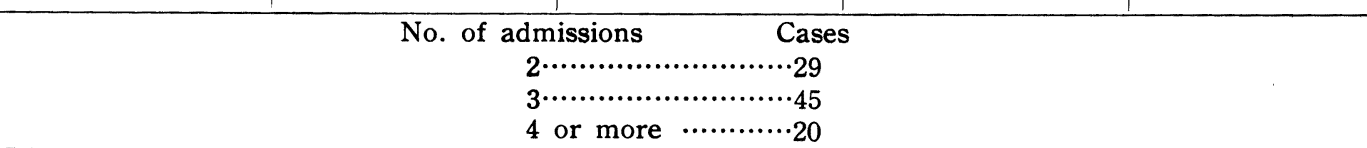 } \\
\hline
\end{tabular}

$\mathrm{N}$ : Normal pattern, B: Borderline, D: Diabetic pattern,

*No females are included. 
Table 5. Relation between changes of G.T.T. pattern and other fiindings (serial studies on 156 cases).

\begin{tabular}{|c|c|c|c|c|c|c|c|c|}
\hline & \multicolumn{2}{|c|}{ Group I } & \multicolumn{2}{|c|}{ Group II } & \multicolumn{2}{|c|}{ Group III } & \multicolumn{2}{|c|}{ Group IV } \\
\hline & \multicolumn{2}{|c|}{$\mathrm{N} \longrightarrow \mathrm{N}$} & \multicolumn{2}{|c|}{$\begin{array}{l}\mathrm{N} \longleftrightarrow \mathrm{B} \\
60 \text { cases }\end{array}$} & \multicolumn{2}{|c|}{$\begin{array}{l}\mathrm{B} \longrightarrow \mathrm{B} \\
44 \text { cases }\end{array}$} & \multicolumn{2}{|c|}{$\begin{array}{l}\mathrm{D} \longrightarrow \mathrm{D} \\
\mathrm{D} \longleftrightarrow \mathrm{B} \\
23 \text { cases }\end{array}$} \\
\hline & No. & $\%$ & No. & $\%$ & No. & $\%$ & No, & $\%$ \\
\hline Physique & & & & & & & & \\
\hline Obese & 1 & 3.4 & 13 & 21.7 & 12 & 27.3 & 13 & 56.5 \\
\hline Normal & 24 & 82.8 & 41 & 68.3 & 28 & 63.6 & 8 & 34.8 \\
\hline Thin & 4 & 13.8 & 6 & 10.0 & 4 & 9.1 & 2 & 8. 7 \\
\hline Serum Cholesterol & & & & & & & & \\
\hline $\begin{array}{l}>250 \mathrm{mg} / 100 \mathrm{ml} . \\
\text { Ocular fundi }\end{array}$ & 2 & 6.9 & 8 & 13. 3 & 7 & 15.9 & 6 & 26.1 \\
\hline Keith-Wagener & 0 & - & 0 & - & 1 & 2.3 & 3 & 13.0 \\
\hline Wagener & 0 & - & 0 & - & 0 & - & 0 & - \\
\hline Persistent & & & & & & & & \\
\hline Albuminuria & 2 & 6.9 & 7 & 11.7 & 3 & 6.9 & 1 & 4.3 \\
\hline Hypertension & 1 & 3. 4 & 6 & 10.0 & 2 & 4.6 & 6 & 26.1 \\
\hline $\begin{array}{l}\text { Abnormal ST in EKG } \\
\text { Absent }\end{array}$ & 3 & 10.3 & 7 & 11.7 & 7 & 15.9 & 6 & 26.1 \\
\hline Ankle jerk & 1 & 3. 4 & 7 & 11.7 & 8 & 18.2 & 11 & 47.8 \\
\hline Infections & & & & & & & & \\
\hline Tbc, active & 0 & - & 0 & - & 0 & - & 1 & 4.3 \\
\hline Tbc, old & 2 & 6.9 & 7 & 11.7 & 4 & 9.1 & 1 & 4.3 \\
\hline Bronchitis (Acute) & 0 & - & 1 & 1.7 & 0 & - & 0 & - \\
\hline Urinary & 0 & - & 1 & 1.7 & 1 & 2.3 & 0 & - \\
\hline Digestive Disease & & & & & & & & \\
\hline Liver damage & 2 & 6.1 & 8 & 13.3 & 7 & 15.9 & 10 & 43.5 \\
\hline Gall stone & 0 & - & 1 & 1.7 & 2 & 4.5 & 0 & - \\
\hline Peptic ulcer & 0 & - & 1 & 1.7 & 2 & 4.5 & 1 & 4.3 \\
\hline Resected stomach & 1 & 3.4 & 2 & 3.3 & 0 & - & 0 & - \\
\hline
\end{tabular}

$\mathrm{N}$ : Normal pattern, B: Borderline, D: Diabetic pattern.

I 群 : 正常型を続けた群.

II群 : 正常型より境界型に移行したり，境界型より正常 型に移行した群.

群 : 境界型を続けた例や，境界型から正常型となり再 び境界型に移行した例.

IV群 : 糖尿病型を続けた例, または一度でも糖尿病型を 呈した例（ただし正常型に戻った 1 例を除く）.

年龄別に G.T.T. の変化を示すと Table 4 のとおり である.46歳以上に正常型を続けた例がない，また，平 均年齢差は I 群と II 群の間に差はなく， II 群と III群の間 で 2 歳上がっている.
体型の変化を見ると正常型を続けた例の中に肥満例は わずか 1 例であるが，IV群中には肥満または肥満化した 者が13例 $56.5 \%$ を占める.

諸病態と比較すると Table 5 のでとくで, 血中総コ レステロール異常はIV群に多く, 肝機能障害とともに, one point study では境界型に多く見られたものが，IV 群に多いことがわかる. また，血管障害を示すものとし て眼底所見異常, 高血圧症, 心電図異常等が IV 群に多 い。また，アキレス腱反射消失例もIV群に高頻度であっ た。

次に運動量についての分析を行なっていないが，課長 
Table 6. Changes in G.T.T. pattern and position in the firm.

\begin{tabular}{|c|c|c|c|}
\hline & Maneger or executive & $\begin{array}{l}\text { Rising from regular } \\
\text { worker to maneger }\end{array}$ & Regular worker \\
\hline $\begin{array}{l}\text { Average age on the first } \\
\text { admission }\end{array}$ & 40.2 & 37.5 & 40.2 \\
\hline Incidence of obesity & $29.5 \%$ & $22.4 \%$ & $21.5 \%$ \\
\hline $\begin{array}{l}\text { Group I } \\
\qquad \mathrm{N} \longrightarrow \mathrm{N} \\
\text { Group II }\end{array}$ & $14 \cdots \cdots \cdots \cdot 23 \%$ & $6 \cdots \cdots \cdots \cdot 12 \%$ & $9 \cdot \cdots \cdots \cdot 20 \%$ \\
\hline Group III & $27 \cdots \cdots \cdots \cdot 34 \%$ & $15 \cdots \cdots \cdots \cdot 31 \%$ & $18 \cdots \cdots \cdot \cdots \cdot 39 \%$ \\
\hline $\begin{array}{l}B \longrightarrow B \\
\text { Group IV }\end{array}$ & $11 \cdots \cdots \cdots \cdot 18 \%$ & $21 \cdots \cdots \cdots \cdot 43 \%$ & $12 \cdots \cdots \cdots \cdot 26 \%$ \\
\hline $\begin{array}{l}\mathrm{D} \longrightarrow \mathrm{D} \\
\mathrm{D} \longleftrightarrow \mathrm{B}\end{array}$ & $9 \cdot \cdots \cdots \cdot 15 \%$ & $7 \cdots \cdots \cdots \cdot 14 \%$ & $7 \cdots \cdots \cdots \cdot 15 \%$ \\
\hline Total & 61 & 49 & 46 \\
\hline
\end{tabular}

$\mathrm{N}$ : Normal pattern B: Borderline pattern, D: Diabetic pattern.

Table 7-1. Incidence of obesity by age in SONY and.Q bank.

\begin{tabular}{c|rl|ll}
\hline Age (yrs.) & \multicolumn{2}{|c|}{ Q Bank } & \multicolumn{2}{c}{ SONY } \\
\hline $31 \sim 35$ & $2 / 10$ & $20.0 \%$ & $10 / 62$ & $16.1 \%$ \\
$36 \sim 40$ & $17 / 52$ & 32.7 & $34 / 132$ & 25.8 \\
$41 \sim 45$ & $16 / 47$ & 34.0 & $13 / 56$ & 23.2 \\
$46 \sim 50$ & $5 / 10$ & 50.0 & $15 / 70$ & 21.4 \\
\hline
\end{tabular}

Table 7-2. Distribution of G.T.T. pattern by age in SONY and Q bank

\begin{tabular}{c|cccc|cccc}
\hline & \multicolumn{4}{|c|}{ Q Bank } & \multicolumn{4}{c}{ SONY } \\
\hline Age (yrs.) & No. & Normal & Borderline & Diabetic & No. & Normal & Borderline & Diabetic \\
$31 \sim 35$ & 10 & $50.0 \%$ & $50.0 \%$ & $-\%$ & 62 & $50.0 \%$ & $45.2 \%$ & $4.8 \%$ \\
$36 \sim 40$ & 52 & 50.0 & 46.2 & 3.8 & 132 & 42.4 & 51.5 & 6.1 \\
$41 \sim 45$ & 47 & 57.4 & 42.6 & - & 56 & 48.2 & 39.3 & 12.5 \\
$46 \sim 50$ & 10 & 40.0 & 50.0 & 10.0 & 70 & 34.3 & 52.9 & 12.9 \\
\hline
\end{tabular}

以上と一般従業員とについて検討すると Table 6 のと おりである. 課長昇格者とは 1 回目の入院時には役付で はなかったが, 最終回の入院時には課長以上に昇格して いた例を意味する．課長以上であった者と，一般從業員 との初診時平均年龄は同じで昇格者群より 2.7 歳高い. また, 肥満の頻度も昇格者群より高い。しかしながら昇 格者群に而群すなわち境界型を取る例が多いととが注目 される.

他企業と比較するため昭和 46 年10月より 47 年 6 月まで
に本院ドックに入院した都内某銀行 (Q-Bank) の31 50 歳の男子119名について検討すると, Table 7 のと打り で肥満者の頻度は Q-Bank に多く, とくに 40 歳以上に 扣いてソニーとの間に推計学的有為差があるが, G.T.T. の異常頻度には有為差がなかった.

現在, 経ロブドウ糖負荷試験は糖尿病の screening に 最も適切な手段であると解釈されて扣り ${ }^{3)}$ ， 日本糖尿病 
学会の勧告案内容に, 診断に際して, 他の身体的条件を 考慮するよう盛り込まれているが4), 多人数の健康管理 やドックの診断に扔いては，それら付記事項はしばしば 無視されがちである.われわれの結果から見ると， G.T.T. の成績が同一型に留まったものは約半数足らず であり，他の病態との比較に打いても one point study と serial study に扔いて, コレステロールや肝機能検 查異常の分布の様子が一变した．まず年龄別に見ると， 2 回以上の検討において, 正常型を保った例が46歳以上 になかったてとは, G.T.T.の成績は年龄により変化し, 後退するととを意味するるのである. 肥満または肥満化 例では G.T.T. が糖尿病型を呈する例が多い。しかし， Q-Bank では 40 歳以上に肥満の頻度が高いが, G.T.T. 異常の頻度はソニーと同程度であり, 肥満は糖代謝異常 の一因とはなるものの糖尿病の素因は肥満に関俰なく分 布されているものと考えられる.

血中総コレステロールは one point study では境界 型に高頻度であったが, serial study ではIV群に多く, 血中コレステロール值が高い例に打いて糖質, 脂質の代 謝異常が恒常化しつつあるてとを示するのである.

血管障害系の検查として, 眼底所見, 常在性蛋白尿, 心電図異常, 高血圧症を挙げたが常在性蛋白 尿を除い $\tau$, 眼底 Keith Wagener, II 度以上, 心電図異常など いわゆる糖尿病らしさ5゙ を示すものがIV群に高頻度であ った. ただし常在性蛋白尿は, 慢性腎炎や前立腺炎例を 除外していないし, 高血圧症については降圧剤使用中の 症例もあるので病歴を参考にした。

肝機能障害はIV群に高頻度であった。これは, 糖尿病 そ打ける脂肪肝の問題が注目されている打りから゙ , 重 要な所見であろう。しかし逆に, 肝機能障害に端を発す る G.T.T. 異常も考光るべきである.

フキレス腱反射異常（両側消失）はIV群では $48 \%$ の高 率で, 細分して見ると, 糖尿病型を続けた例では60\%に 異常があり, 境界型から糖尿病型に移行した13例中 6 例 に異常があった。これは而群に比しきわめて高頻度であ り, 糖尿病性末梢神経障害が G.T.T. の糖尿病型化に先 行するという説を考えると，きわめて重要な所見である てとがわかる7). 著者らの調查では, G.T.T. に扎いて 血中 IRI を測定し負荷後 30 分の血糖上昇に対する血中 IRI 值の上昇を $30^{\prime} \Delta \mathrm{I} / \Delta \mathrm{G}$ として表現すると, G.T.T. 境界型例に扣いて $30^{\prime} \Delta \mathrm{I} / \Delta \mathrm{G}$ が低い例に, 末梢神経障 害を有する頻度が高く, 逆に, 末梢神経障害所見を有す る例は，必ずといえるくらい $30^{\prime} \Delta \mathrm{I} / \Delta \mathrm{G}$ が低值であっ $た^{8)}$.
職種別の G.T.T. の推移を見ると (Table 6), 昇格者 群に境界型例となる者が多く, 課長以上の群と一般従業 員では四群にはいるものはむしろ少なかった，昇格者群 では平均年跲も低く, 肥満の頻度も低いのに G.T.T. 異 常がやや高頻度になるととは, 断言できないが，モーレ ツ働きによる精神的ストレスを否定する訳にはいかな い.

第 1 回の入院より最後の入院までの間に胃切除を受け た例が 3 例あった。 うち 2 例は Oxyhyperglycemia を 呈したが 1 例は正常型のままであった。 また， 3 例の胆 石症では 2 例が胆のう摘出術を受けたがうち 1 例は G.T.T. が正常型となった．また，糖尿病型より正常型 に移行した 1 例は，第 1 回目入院時, 白血球数約 12,500 に上がる急性気管支肺炎の経過中であった．また肺結核 が再然して G.T.T.が境界型より楉尿病型となった例も あった。

以上の結果より見て，G.T.T. の成績は年龄により体 型によりまた他の身体的因子により常に流動的である. しかしながら 1 回でも G.T.T. が糖尿病型を呈するIV群 に, 血中総コレステロール值の異常やアキレス腱反射の 異常頻度が高く, 例数は少ないが, 眼底異常や心電田異 常も高頻度に見られ糖尿病的病態の特徵を現わしつつあ るといえよう。したがって一度でも糖尿病型を呈した例 ではたとえ正常型に移行しても注意深い追跡が必要であ る.また境界型例は一回の G.T.T.による診断はつけが たく他の身体所見とあわせ考虑しつつ follow up すべ きであろう. 本調査において, 糖尿病型を続けた例が 156 例中 5 例である.

Krosnik ${ }^{9}$ によると New Jersey 州の 180,000 人の労 働者の糖尿病の頻度は事業主からの報告では $0.5 \%$ と伝 えられているが, 事実上は $2 \sim 3 \%$ 報告している. 本 邦では後藤ら ${ }^{10)}$ によると 40 歲以上の京浜地区工業労働 者, 1,061 人の調査では $1.3 \%$ あるるいう.ソニー社内の 事業所より 3 カ所について調査した結果 4, 472 名の男子 のうち糖尿病として管理されている者52名, 疑糖尿病と して管理されている者 80 名で, 糖尿病の頻度は $1.2 \%$ で あり一般に報告されている比率とはぼ同じである.しか し，47年度の定期健康診断の結果を本社のみについて見 ると男子受診者 1,830 人（現在糖尿病として管理中の 30 名を除く）中糖尿陽性者は52人に上った．それらの例に ついて600 800カロリーの社員食堂の定食摄取後行なっ た食後 2 時間血糖が $120 \mathrm{mg} / \mathrm{d} l$ 以上である例は 18 人で, うち 6 人が 100 グラム G.T.T. で糖尿病型を呈した。し かし上述の理由により一回の G.T.T. で糖尿病と診断す 
ることに慎重な態度を取って，今後経過を追跡する必要 がある。

現在日本人の食生活の欧米型化は急速であり, 今後, 1 回だけの検査で尿糖陽性者や G.T.T. 糖尿病型例の頻 度は増加するものと考えられる．糖尿病はコントロール されている限り病気と考える必要はなく, Tetrick ${ }^{11)} に$ よると糖尿病者の大部分は就莱可能であり, しかも一度 就職した後は, 非糖尿病者との間に仕事上の信頼度の差 がないてとを認めている.しかし one point の検査だけ では診断が困難な軽症者が多い. 境界型例や糖尿病型例 では，他の身体条件とくに合併症を考虑しつつ follow up して，個人の健康管理に資すべきであろう.

\section{総括}

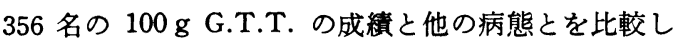
た. 次にその中から 2 回以上 G.T.T. を追跡検査した 156 名において G.T.T. の恒常性と他の病態とを比較し た. G.T.T. の型が変化しない例は半数以下であり, 年 龄や他の身体的因子によりさわめて流動的であり一回の G.T.T. のみから診断をつけがたい場合が多い.しかし 一度でも糖尿病型を呈する例では末梢神経障害や血管障 害等の糖尿病の本質的所見を呈する頻度が高い.

肥満怔糖㴬異常の一因ではあるが，糖尿病化の因子 は別のようであり，糖尿病素因の分布は肥満に関係なく ソニーに打いても他企業とほぼ同じである.

糖尿病者の仕事上での信頼度は非糖尿病者と差がない ことからも，糖尿病従業員の健康管理は価值のあること である. 同時に早期糖疗病や，境界例に扣いても 1 回の
みの検査で済ませることなく追跡すべきである.

終わりにご指導下さった済生会中央病院々長堀内光先生に深 謝する、またご尽力くださったソニー健康管理室の諸兄姉に深 謝する.

\section{文献}

1) Krall, L. P.: When is diabetes, Med. Clin. N. Amer, 49: 893-904, 1965.

2）小林芳人：糖尿病集団検診に拈ける諸問題，日本医学会 総会学術講演集, 第16回, IV: 302-306, 1963.

3) Marks, H. H., Krall, L. P. and White, P.: Epidemiology and detection of diabetes. Joslin's Diabete Mellitus, 10-34, Lea \& Febiger, Philadelphia, 1971.

4）葛谷信貞 (委員長)：糖負荷試験における糖尿病診断基準 委員会報告, 糖尿病, 13: 1-7, 1970 .

5) 堀内 光, 松岡健平 他: Angiopathy of diabetes mellitus in Japan. Excerpta Medica International Congress Series No. 221, 205-211, Excerpta Medica, Amsteldam, 1970.

6) Beringer, A. and Thaler, H.: The relation between diabetes mellitus and fatty liver, Germ. Med. Mth, 15: 615-618, 1970.

7) Ellenberg, M.: Diabetic Neuropathy, 糖尿病, 12: 429-433, 1969.

8) 松岡健平, 堀内 光 他: 糖尿病性末梢神経障害と血中 IRI 值, 糖尿病, 15, Supple., 205, 1972.

9) Krosnik, A.: The diabetic employee in New Jersey industry, The 16th Int. Cong. Occup. Health., 1969.

10）後藤由夫, ほか：糖尿病の集団検診と管理指導, 内科, $29,467-475,1972$.

11) Tetrick L. and Colwell, J. A.: Employment of the diabetic subject, J. Occup. Health, 13: 380$383,1971$. 